\title{
Functional food plants in Debre Markos district, East Gojjam, Ethiopia
}

\author{
HIRUT BELAY, TIGIST WONDIMU* \\ Department of Biology, Addis Ababa University. Addis Ababa, Ethiopia. `Email: twtigistw@gmail.com.
}

Manuscript received: 11 September 2018. Revision accepted: 16 May 2019.

\begin{abstract}
Belay H, Wondimu T. 2019. functional food plants in Debre Markos district, East Gojjam, Ethiopia. Asian J Ethnobiol 2: 8-21. An ethnobotanical analysis of functional food plants was conducted in Debre Markos District, East Gojjam, Ethiopia, to record indigenous knowledge. Ethnobotanical methods were used to collect data from October 2015 to July 2016. Ten of 21 villages in this district were chosen randomly to perform the analysis. A total of 80 informants (61 men and 19 women) ranging in age from 20 to 79 were selected to participate in the study and provide information on functional food plants grown and used in the District. Twenty of the 80 informants were chosen (as key informants) based on recommendations from elders and kebele administrators, while the rest were selected at random. Semi-structured interviews and group discussions were used to gather ethnobotanical data. As functional food plants grown in the District, 29 species from 27 genera and 19 families were identified. The Poaceae and Fabaceae families proved to be the most diverse, with 5 and 4 species, respectively. Herbs (23), shrubs (3), and trees (3) are the species' habits (growth forms). Grains $(23.4 \%)$ and leaves $(23.4 \%)$ were the most commonly used plant components $(13.8 \%)$. Cooking/boiling seeds was the most common form of preparation (23.4\%), followed by raw/unprocessed seeds (12.9\%). According to informant consensus, Lupinus albus L. (Gibto) was the most commonly recorded species (90\%), followed by Eragrostis tef L. (Dabbo teff) (78.8\%). Linum usitatissimum L. (Telba) was the most favored species for preventing multiple diseases in a preference rating. Based on the general use-value of functional food plants, a direct matrix analysis showed that Eragrostis tef L. (Dabbo teff) was the most important species. Cinnamomum verum L. was identified by the fidelity level index. Lupinus albus L. (Kerefa) (Gibto) has a high practical benefit in preventing diabetes mellitus and hypertension. The loss of agricultural lands due to new building construction was a critical threat to a few functional food plants such as Lupinus albus (Gibto) in the study area. The Woreda is in the central city of East Gojjam Zone. As a result, stalk owners must focus on resolving the problem.
\end{abstract}

Keywords: Debre Markos, ethnobotany, functional food plants, indigenous knowledge, phytochemicals

\section{INTRODUCTION}

Ethiopia is a country with a diverse range of climatic and ecological conditions and a large variety of flora and fauna. Furthermore, the country's high geographic heterogeneity and the various cultural diversity of the different ethnic groups resulted in a wide range of traditional expertise and practice (Asfaw 2001). Maintaining sustainable food production while delivering high-quality products with added versatility to prevent lifestyle-related diseases is challenging in food productivity and development research. (Wang and Bohn 2012).

Over and beyond standard diet, functional foods have health benefits. Functional foods differ from medicinal foods and dietary supplements in that they can be consumed freely as part of daily life. Medicinal foods and drugs are typically used to treat disease in specific cases. On the other hand, dietary supplements overlap with foods developed for specific dietary purposes and fortified foods (Ross 2000).

Most Functional Foods that have been shown to reduce lipid and cholesterol levels, increase bone mineral density and antioxidant status, and possess anticancer properties, are derived from plants (legumes, cereals, grains, fruits, and vegetables) with a few exceptions (Eskin and Tamir 2006). However, only a handful of the hundreds of plantbased functional foods that have been documented have been integrated into everyday foods (Wang and Bohn 2012).

According to Kassaye et al. (2006), healing in Ethiopian traditional medicine is about curing diseases and preserving human physical, spiritual, social, emotional, and material well-being. This means that Ethiopians have a long history of traditional knowledge about the role of food plants. Functional food plants are still widely used in Ethiopia, and their acceptability, availability, and popularity are undeniable, given that the majority of the population consumes them. People in Debre Markos District, like people in Ethiopia, have cultural activities passed down from generation to avoid such human diseases. However, according to FAO (1995), indigenous knowledge is rapidly disappearing in many parts of the world, including Ethiopia, due to changes in lifestyle, occupational habits of household members, and the death of knowledgeable people.

According to information obtained from Debre Markos University's Botanical Department and the researcher's opinion, no ethnobotanical research on "functional food plants" has been conducted in the Debre Markos District. By researching and recording historically used functional food plants in Debre Markos District, this study aimed to fill a gap in the country's limited functional food plant use inventory. The research will provide helpful information on the status of functional food plants and their application in 
the study field. This will serve as a baseline for future studies.

The goals of the study were (i) to identify and record the people's indigenous knowledge of functional food plants in the study area, (ii) to classify and record the most significant functional food plants used by Debre Markos District residents, (iii) to show the way local people in the study area use plant parts as functional foods and the way they prepare them.

\section{MATERIALS AND METHODS}

\section{Study area}

The geographical location of the study area

Debre Markos is one of 18 Districts of East Gojjam Zone and 151 districts in Amhara National Regional State (DMDARDO 2015). It is the largest town in the East Gojjam Region, its located about 295 kilometers from Addis Ababa and 265 kilometers from Bahir Dar, the ANRS's capital. It is made up of 7 kebeles. Its elevation is between 2,420 and 2,509 meters above sea level, and its geographical coordinates are $10^{\circ} 20^{\prime \prime} \mathrm{N} .37^{0} 43^{\mathrm{ce}}$ E. $110^{\circ}$ $333^{\prime \prime}$ N. $37^{0} 717^{\prime \prime}$ E. (Figure 1). The district is bordered on the east, north, and the west by the Gozamin district and the south by the Aneded district. The Woreda's topography is mostly $98 \%$ plane and 2\% plateau (DMDFEDO 2015).

\section{Soil and drainage}

Clay and black soil are the two most common soil types in Debre Markos District, accounting for roughly $73 \%$ and $27 \%$ of the total area. The district's topography, vegetation, and rainfall pattern promote the existence of a few perennial rivers, such as Wetrin, Weseta, and Chemoga, which have been used for irrigation in the past (DMDARDO 2015).

\section{Climate and ecology}

The agro-climatic region is traditionally known as "weina-dega," with average annual temperatures varying between 15 and $20^{\circ} \mathrm{C}$ (Figure 2). The district is known for its unimodal raindrops, with the total yearly rainfall falling between the end of April and the end of October, with an average annual range of $1200 \mathrm{~mm}$ and $1380 \mathrm{~mm}$ (Figure 3 ) (DMDARDO 2015).
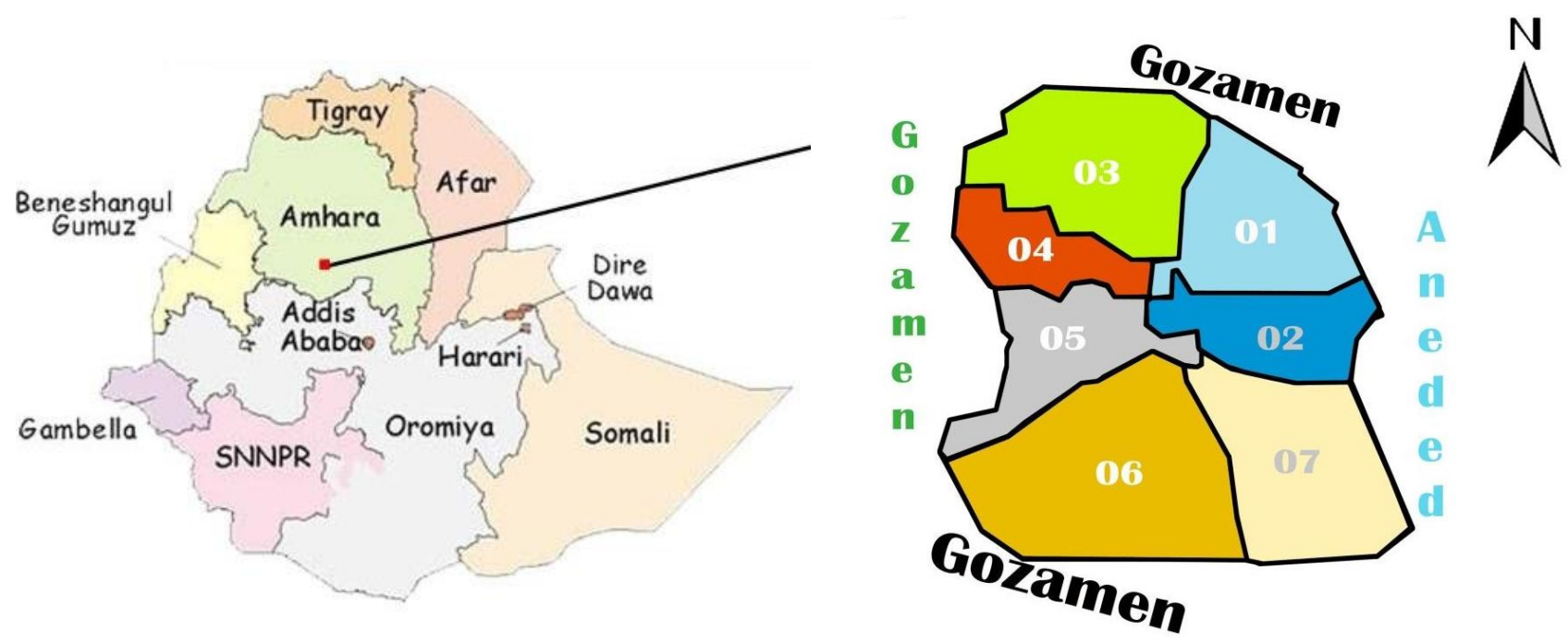

Figure 1. -Map of Debre Markos District (source: DMDFEDO 2015)

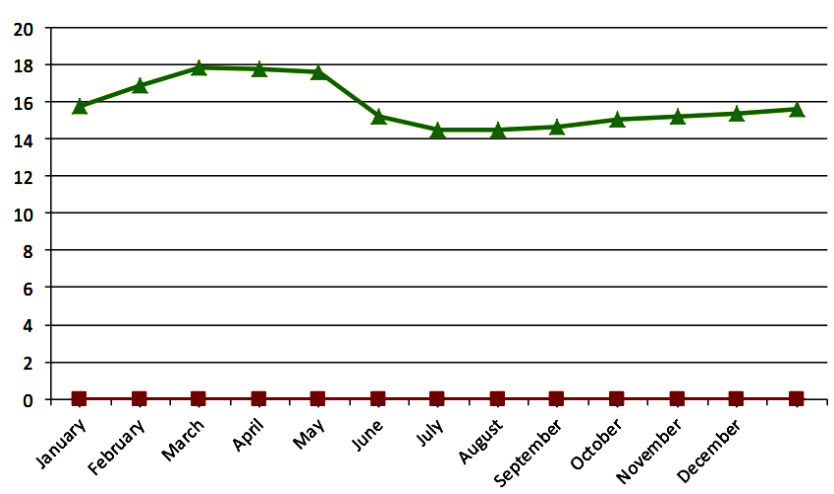

Figure 2. The monthly temperature of Debre Markos District 2015 (Source of data: -Versat international LLC)

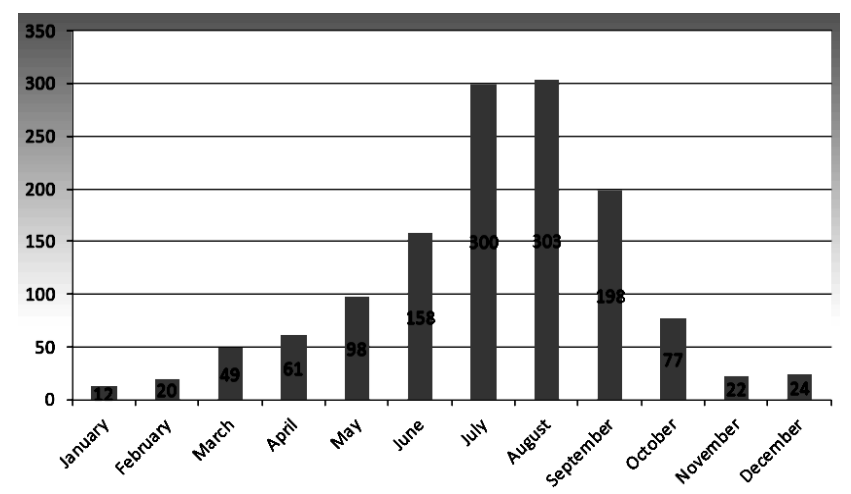

Figure 3. Monthly precipitation of Debre Markos District 2015 (Source of data:-Versat international LLC) 
Crop production is mainly dependent on rain and smallscale irrigation. Only one rainy season (known locally as "kiremt") is critical for cultivating long- and short-cycle crops.

The area's agricultural system is a mixed farming system, in which crop production is multiple cropping with a small amount of land used intensively. Crop rotation, which alternates cereal production with legume crop production to preserve soil fertility, has traditionally been used to practice continuous cropping. The food crops grown in the district include cereal (wheat, teff, maize, barley, engedo, oat), fruits (papaya, pom, cocks, limes, oranges, mangoes, bananas, gibberries), vegetables (garlic, chocolate, tomatoes, pumpkins, salad, Kosta), root crops (sweet potatoes, potatoes, reddish, carrots) and cash crops, including the cereal crop, (cereals, pumpkins, gibberries, etc.), and (DMDARDO 2015). Land use and agricultural system

The district covers a total area of 6,160 hectares. The majority of the land is for farming purposes (2,363 ha, and $38,36 \%$ ), followed by residential, road, and water areas of 1,995 ha, according to information obtained from DMDARDO (2015). (32.4\%). Other land characteristics share significant areas, as listed in Table 1.

\section{Population structure and medical service}

The district has a total population of 107,433 people, with 50,036 males and 57,397 females. Rural dwellers account for 1,268 (1,053 males and 215 females) of the total population, while urban dwellers account for 106,165 (48,983 males and 57,182 females). The Amhara (98\%), Oromo $(0.8 \%)$, and other ethnic groups are the most numerous in the district $(1.2 \%)$. 1Amharic is the first language of $99.3 \%$ of the population, and Orthodox Christianity is practiced by the majority (96\%) of the people, whereas Protestantism and Islam are practiced by the remainder (DMDFEDO 2015).

According to DMDHHIV/AIDSPCO (2015), the first top ten human diseases in the area are acute upper respiratory infection with 3,431 (20.53\%) of infected people, followed by Dyspepsia (gastritis) with 1,984 $(11.87 \%)$ of infected people and the others are mentioned on Table 2.

However, according to DMDHHIV/AIDSPCO (2015), few people of Debre Markos are affected by chronic diseases such as diabetes, hypertension, heart disease, and cancer, with numbers $104,432,5,12$, respectively.

Table 1. Land use patterns of Debre Markos District, Ethiopia

\begin{tabular}{lll}
\hline Land use & Area (ha) & Percentage \\
\hline Agricultural land & 2363 & 38.36 \\
Residence, road, and water bodies & 1995 & 32.40 \\
Grazing land & 815 & 13.23 \\
Forest areas & 624 & 10.12 \\
Irrigation areas & 363 & 5.89 \\
Total & 6160 & 100 \\
\hline Sol
\end{tabular}

Source: DMDARDO (2015)
Table 2. Top ten human diseases in Debre Markos District, Ethiopia

\begin{tabular}{lcc}
\hline \multicolumn{1}{c}{ Type of disease } & $\begin{array}{c}\text { No. of people } \\
\text { affected }\end{array}$ & Percentage \\
\hline Acute upper respiratory infection & 3431 & 20.53 \\
Dyspepsia (gastritis) & 1984 & 11.87 \\
Acute febrile illness & 1891 & 11.31 \\
Parasitic disease & 1600 & 9.57 \\
The disease of the musculoskeletal & 1506 & 9.01 \\
system and connective tissue & & \\
Urinary tract infection & 1407 & 8.42 \\
Diarrhea & 1338 & 8.01 \\
Un specified digestive system disease & 1305 & 7.81 \\
Eye disease & 1159 & 6.93 \\
Pneumonia & 1093 & 6.54 \\
Total & 16714 & 100 \\
\hline Source DMDHHIV/AIDSPCO (2015) & & \\
\end{tabular}

Source: DMDHHIV/AIDSPCO (2015)

\section{MATERIALS AND METHODS}

\section{Design of the research}

This cross-sectional study aimed to investigate and document the functional food plants in the Debre Markos District. From September 30, 2015, to November 12, 2015 , the collection of journals and other literature was employed. A reconnaissance survey was carried out from October 5 to November 5, 2015. The deadline for developing and submitting proposals was November 27, 2015. Data collection took place from December 22, 2015, to the first two weeks of March 2016, and thesis development took place from the middle of April to the end of June 2016.

\section{Reconnaissance survey and selection of starting}

Before starting the actual study, a reconnaissance survey was conducted from October 5 to November 5 , 2015 , to gather information about functional food plants and identify sampling sites. Ten representative villages were chosen from seven kebeles (Table 3). To determine the number of representative villages, the population size and number of villages in each kebele were considered, and random selection was used to assess sample sites from each kebele. As a result, the study sites were chosen using a systematic simple random sampling method.

\section{Selection of informants}

A total of 80 informants (61 males and 19 females) aged 20 to 79 years were chosen, with the number of informants from each kebele determined systematically based on the proportion of the population size. In addition, twenty elders and knowledgeable people were identified as critical informants through purposive sampling (Martin, 1995), and other informants were chosen at random from the sampled villages. The key informants were selected based on the recommendations and comments of community elders, farmers, students, religious leaders, and the researcher's observations. Age group, educational and marital status of informants shows in Table 4 
Table 3. Study kebeles with their corresponding sampling site and no. of informants participated

\begin{tabular}{llccc}
\hline $\begin{array}{c}\text { Study } \\
\text { kebeles }\end{array}$ & Sample villages & $\begin{array}{c}\text { Population } \\
\text { size }\end{array}$ & $\begin{array}{c}\text { Number of } \\
\text { informants }\end{array}$ & Total \\
\hline 1 & Endegem & 12762 & 9 & 9 \\
2 & Engecha & 13505 & 10 & 10 \\
3 & Shola amba & 27163 & 13 & 21 \\
& Yebragie & & 8 & \\
4 & Yemeka & 14000 & 10 & 10 \\
5 & Kebi achira & 18016 & 7 & 13 \\
& Muakuat & & 6 & \\
6 & Yenora & 10921 & 7 & 7 \\
7 & Abedeg & 11066 & 6 & 10 \\
& Chemoga & & 4 & \\
Total & 10 & 107433 & 80 & 80 \\
\hline
\end{tabular}

Note: Source of population data: DMDFEDO, (2015)

Table 4. Demographics

\begin{tabular}{|c|c|c|c|c|}
\hline & \multirow[t]{2}{*}{ Age group (in yrs.) } & \multicolumn{2}{|c|}{$\begin{array}{c}\text { Sex and no of } \\
\text { informants }\end{array}$} & \multirow[t]{2}{*}{ Total } \\
\hline & & Male & Female & \\
\hline \multirow[t]{4}{*}{ Age group } & $20-30$ & 13 & 5 & 18 \\
\hline & $35-49$ & 21 & 10 & 31 \\
\hline & $50-64$ & 20 & 3 & 23 \\
\hline & $65-79$ & 7 & 1 & 8 \\
\hline \multirow[t]{4}{*}{ Education level } & Illiterate & 12 & 3 & 15 \\
\hline & Only read and write & 22 & 9 & 31 \\
\hline & Modern education & 20 & 7 & 27 \\
\hline & Church education & 7 & - & 7 \\
\hline \multirow{3}{*}{ Marital status } & Single & 6 & 2 & 8 \\
\hline & Married & 53 & 15 & 68 \\
\hline & Divorce & 2 & 2 & 4 \\
\hline
\end{tabular}

In the study area, eighty informants were divided into four age groups. They were young (20-34), middle-aged (35-49), elder (50-64), and elderly (65-79). The middleaged groups had the highest number of informants. Males outnumbered females (61 to 19). The majority of the informants (31) could read and write. Approximately 68 of the total informants were married (Table 4).

\section{Ethnobotanical data collection}

Ethnobotanical data were collected from December 22, 2015, to March 21, 2016. Ethnobotanical information covers different types of functional food plants, cured diseases, parts used, and preparation methods, following the data collection tools recommended by Martin (1995).

Semi-structured interview-Ethnobotanical data was collected through semi-structured interviews using checklist item questions written in English (Appendix 2) and later translated into Amharic. The items include information on the informant's identity, a local health problem, the names of functional food plants, the part(s) used, preparation methods, and disease management. The entire informant interview was conducted directly between the researcher and the informants (Figure 4). Before starting data collection, informants' willingness was confirmed. This was accomplished by raising informant awareness by describing the future significance of the research for the study area and the country.

Group discussion-Short and detailed group discussions were held with informants about the functional food plants in the study sites. Local names of functional food plants, their uses, preparation methods, indigenous knowledge about them, and other data were collected.

\section{Functional food plant specimen collection and identification}

During a guided field walk, the voucher specimens were collected, numbered, pressed, and dried for the title. Flora of Ethiopia and Eritrea was used for identification with assistance from the Biology Department of Debre Markos University, Ethiopia.
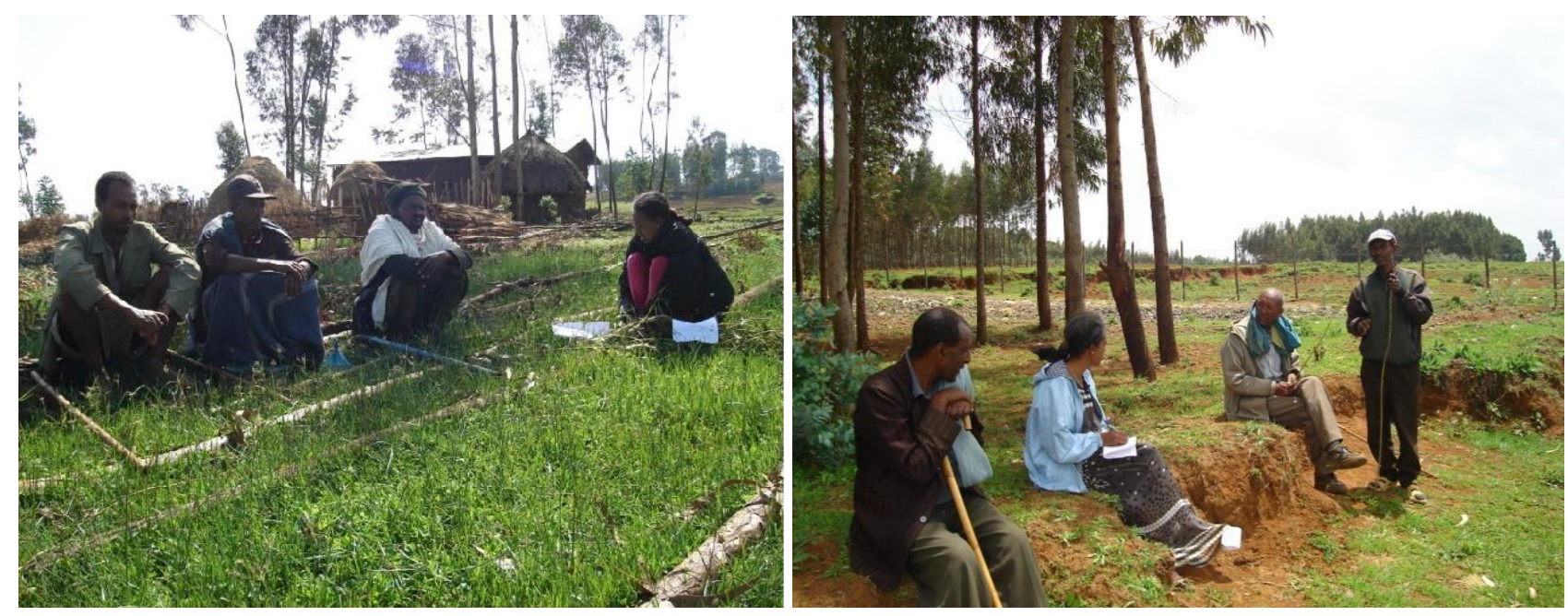

Figure 4. Photographs showing group discussion to key informants during ethnobotanical data collection 


\section{Data analysis}

Descriptive statistics

The ethnobotanical data was analyzed using survey and analytical techniques that Martin (1995) and Alexiades (1996) recommended for ethnobotanical methods. The data on functional food plants and associated information obtained from informants in the study area were analyzed and summarized using descriptive statistical methods. The most helpful information gathered on functional food plants identified by local people, including functional importance and preparation, was analyzed using appropriate software and descriptive research methods.

\section{Informant consensus}

Informants were consulted to assess the reliability of the information provided during the interview. It was dismissed as irrelevant if the informant's idea differed from the original report. Only the most important ones were considered and statistically analyzed; Alexiades' approach was used (1996). Similarly, the informant consensus factor was quantitatively analyzed for six plant uses identified by informants.

\section{$\mathrm{ICF}=$ nur-nt $/$ nur-1}

Where,

ICF: Informants Consensus Factor

Nur: Number of citations in each category

$\mathrm{Nt}$ : Number of species used

\section{Preference ranking}

For most functional food plants used to prevent the most prevalent disease in the study field, preference (priority) ranking was performed using seven primary informants. As a result, key informants selected five functional food plants to be rated preferentially on a numerical scale for preventing Gastritis ( 0 for no value, 1 for lowest value, and 5 the highest value, and the rest with intermediate values). The values provided by the primary informants were combined to determine the community's preference for functional food plants in the study area. The highest score was placed first, while the lowest was placed last, and the rest were assigned different ranks based on the study results. A similar study on six functional food plants was conducted to see how effectively they prevented various diseases.

\section{Direct matrix ranking}

Direct matrix ranking compares the multiple purposes of plants commonly identified by informants (Cotton, 1996). Thus, a direct matrix ranking exercise was conducted on eight functional food plants based on the relative benefits obtained from each plant during the general group discussion and semi-structured interviews with key informants. Use values to each attribute assigned as (5-best, 4-very good, 3-good, 2-less used, 1-least used, and 0-no used) based on their perceived degree of usefulness; later, the value assigned for each plant were added together to decide its rank.

\section{Fidelity level index}

The fidelity level index (FL) is utilized to prove that certain plant species are used for the same main reason (Alexiaden, 1996). As a result, the fidelity level for functional food plants used to Prevent Diabetes and Hypertension was determined. The degree of fidelity is measured as follows:

$$
\mathrm{FL}(\%)=(\mathrm{NP} / \mathrm{N}) \times 100
$$

\section{Where}

NP: Number of informants that claim the use of a plant species to prevent a particular disease

$\mathrm{N}$ : Number of informants who use the plant as a functional food, as Alexiades (1996) described.

\section{RESULTS AND DISCUSSION}

\section{Status of indigenous knowledge related to functional food plants in the study area}

The study area residents use a variety of functional food plants to prevent and treat various diseases. Except for a few (such as tuberculosis, pneumonia, and acute diarrhea), several health problems are thought to have plant or spiritual remedies in the region. These people use a variety of functional food plants to prevent and treat various diseases and improve their immunity. According to informants, information regarding functional food plants as a health feature was collected informally from friends or elders of neighbors, often mainly in conversation and mainly during the outbreak of a health-related issue. The second most common source of information acquisition was from family members who learned from their parents, accounting for $20 \%$ of all responses.

The majority of indigenous knowledge is acquired orally from elders, parents, or relatives, as it is done elsewhere (Abbasi et al., 2013). As a result, the information-transfer mechanism can challenge indigenous knowledge. Indigenous information is rapidly disappearing in many parts of the world, including Ethiopia, due to changes in lifestyle, changing occupational habits of household members, and the death of village elders (FAO, 1995). Many people interviewed for this study believe that modernization is endangering the information system.

\section{Functional food plants in the study area}

Distribution of functional food plants among taxa

During the research, 29 species from 27 genera and 19 families were described and reported. The Poaceae family proved to be the most numerous, with six species divided into five genera, followed by the Fabaceae family, which had four species divided into four genera. This could be because these are the most abundant, widely used, and cultivated food plants in the area. Solanaceae had two species and two genera, Rutaceae had two species under one genus, and the remaining (15) had one species (Table $5)$. This shows a high diversity of functional food plants in the study field and their use. 
Diversity of habits (growth forms) of functional food plants

Herbs are the most common group of functional food plants in the study field, accounting for 23 species (79.3\%), followed by shrubs and trees, each with 3 species $(10.34 \%)$ (Figure 5).

\section{Human diseases and the corresponding number of Functional Food Plant species used in the study area}

A total of 29 food plant species have been shown to have anti-disease and immunity-boosting properties. The majority of them are local species widely used in the study area's culture. Apart from that, most of them are traditional foods, and their preparation methods are close to those used in our daily diet (Table 6).

As a result, about 19 human diseases have been avoided or healed by 29 plant species. In the study region, 13 diseases are prevented by using two or more Functional Food Plant species, and six are controlled by using only one plant species (Table 7). Chronic diseases were sporadic among the top ten illnesses identified by DMDHIV/AIDSPCO in 2015, indicating that the population's lifestyle is more closely linked to the use of Functional Foods; Functional Foods have a beneficial impact on improving health, preventing and reducing chronic disease risk factor (Roberfroid 2003).

The documentation demonstrates the use of significant numbers of functional food plants by Gastrontia with 8 species followed by Hypertension using 7 species; Cancer 6; Microbial and Diabetes with 5 species each and then Constipation with 4 species each (Table 8). This shows that various functional food plants in the field of study can prevent a particular disease.

\section{Plant parts used as a functional food}

Different sections of the plant were stated to be used for functional purposes in this research. According to the results of the interviews, grains were the most widely used plant components, accounting for $(14 ; 48.3 \%)$, followed by leaves $(4 ; 13.8 \%)$, tuber $(3 ; 10.3 \%)$, fruits and grains $(3$; $10.3 \%)$, fruits $(2 ; 6.9 \%)$, roots, barks, and bulb $(1 ; 3.4 \%)$ (Figure 6). Functional food plants are regularly part of a diverse diet at an appropriate stage. As a result, grain is the most common standard edible component of plant species that is expected to have functional value in the study field.

\section{Methods of preparation of functional food plants}

Diverse processing of functional food plants is practiced in the local communities of the Debre Markos district; most of them are cook/boil (37.9\%) followed by raw (20.7\%), powder/baking (17.2\%), and Fluid/juice account $(17.2 \%)$. Other forms of preparations are also shown (Table 9).

Table 5. Number of Functional Food Plant species in each family in the studying area

\begin{tabular}{|c|c|c|c|c|c|c|c|}
\hline Family & Scientific name & Vernacular name & Habit & $\begin{array}{l}\text { No. of } \\
\text { genera }\end{array}$ & $\begin{array}{l}\text { No. of } \\
\text { species }\end{array}$ & $\begin{array}{l}\text { Percentage of } \\
\text { plant species }\end{array}$ & Abundance \\
\hline Alliaceae & Allium sativum & Nech shinkurt & Herb & 1 & 1 & 3.44 & Common \\
\hline Apiaceae & Daucus carota & Carrot & Herb & 1 & 1 & 3.44 & Common \\
\hline Asteraceae & Guizotia abyssinica & Nug & Herb & 1 & 1 & 3.44 & Common \\
\hline Brassicaceae & Brassica carinata & Yabeshagomen & Herb & 1 & 1 & 3.44 & Common \\
\hline Caricaceae & Carica papaya & Papaya & Tree & 1 & 1 & 3.44 & Common \\
\hline Chenopodiaceae & Beta vulgaris & Key sir & Herb & 1 & 1 & 3.44 & Common \\
\hline Cucurbitaceae & Cucurbita реро & Duba & Herb & 1 & 1 & 3.44 & Common \\
\hline \multirow[t]{4}{*}{ Fabaceae } & Cicer arietinum & Shimbra & Herb & 4 & 4 & 13.79 & Common \\
\hline & Lupinus albus & Gibto & Herb & & & & Common \\
\hline & Trigonella foenum graecum & Abish & Herb & & & & Common \\
\hline & Vicia faba & Bakela & Herb & & & & Common \\
\hline Lamiaceae & Thymus schimperi & Tosign & Herb & 1 & 1 & 3.44 & Rare \\
\hline Lauraceae & Cinnamomum verum & Kerefa & Tree & 1 & 1 & 3.44 & Rare \\
\hline Lineaceae & Linum usitatissimum & Telba & Herb & 1 & 1 & 3.44 & Common \\
\hline Pedaliaceae & Sesamum orientale & Selit & Herb & 1 & 1 & 3.44 & Rare \\
\hline \multirow[t]{6}{*}{ Poaceae } & Avena sativa & Engedo & Herb & 5 & 6 & 20.68 & Common \\
\hline & Eragrostis tef & Dabbo teff & Herb & & & & Common \\
\hline & Hordeum vulgare & Gebis & Herb & & & & Common \\
\hline & Sorghum bicolor & Zengada & Herb & & & & Common \\
\hline & Triticum dicoccon & Ajja & Herb & & & & Common \\
\hline & Triticum aestivum & Sendie & Herb & & & & Common \\
\hline Ranunculaceae & Nigella sativa & Tikurazemud & Shrub & 1 & 1 & 3.44 & Rare \\
\hline \multirow[t]{2}{*}{ Rutaceae } & Citrus aurantifolia & Lomi & Shrub & 1 & 2 & 6.89 & Common \\
\hline & Citrus sinensis & Birtukan & Shrub & & & & \\
\hline \multirow[t]{2}{*}{ Solanaceae } & Lycopersicon esculentum & Timatim & Herb & 2 & 2 & 6.89 & Common \\
\hline & Solanum tuberosum & Dinich & & & & & Common \\
\hline Theaceae & Camellia sinensis & Shay kitel & Tree & 1 & 1 & 3.44 & Rare \\
\hline Urticaceae & Urtica simensis & Sama & Herb & 1 & 1 & 3.44 & Common \\
\hline Zingiberaceae & Zingiber officinale & Zingiber & Herb & 1 & 1 & 3.44 & Common \\
\hline
\end{tabular}


Table 6. List of functional food plants

\begin{tabular}{|c|c|c|c|c|c|c|}
\hline $\begin{array}{l}\text { Scientific name of } \\
\text { functional food plants }\end{array}$ & Family & $\begin{array}{l}\text { Local name in } \\
\text { Amharic }\end{array}$ & HbH & Pp & Disease type & Method of preparation \\
\hline Allium sativum $\mathrm{L}$. & Alliaceae & Nech shinkurt & $\mathrm{H} \mathrm{Hg}$ & Bulb & $\begin{array}{l}\text { Cancer, } \\
\text { hypertension. } \\
\text { Microbial disease }\end{array}$ & $\begin{array}{l}\text { Crush the bulb of Allium sativum and daily prepare it as in "watt." } \\
\text { Crush the bulb and add with tea or honey. }\end{array}$ \\
\hline Avena sativa $\mathrm{L}$. & Poaceae & Engedo & $\mathrm{H} \mathrm{CU}$ & Grain & $\begin{array}{l}\text { Diabetes, general } \\
\text { weakness, } \\
\text { osteoporosis. }\end{array}$ & $\begin{array}{l}\text { Grind and bake the grain of Avena sativa to form "injera" or mix the grain powder with Hordeum } \\
\text { vulgare and Triticum dicoccon and boil it to make "atmit" (gruel). }\end{array}$ \\
\hline Beta vulgaris $\mathrm{L}$. & Chenopodiacea & eKeysir & $\mathrm{H} \mathrm{Hg}$ & taproot & Hypertension & Roast or cook the taproot of Beta vulgaris. \\
\hline $\begin{array}{l}\text { Brassica carinata } \\
\text { A.Braun }\end{array}$ & Brassicaceae & $\begin{array}{l}\text { Yabeshago } \\
\text { men }\end{array}$ & $\mathrm{H} \mathrm{Hg}$ & Leaf & $\begin{array}{l}\text { Constipation and } \\
\text { cancer }\end{array}$ & Chop the leaf of Allium cepa and cook it with oil for a few minutes. \\
\hline Camellia sinensis $\mathrm{L}$. & Theaceae & Shay kitel & $\mathrm{T} \mathrm{Cu}$ & Leaf & Heart disease & In water, boil the leaf of Camellia sinensis. \\
\hline Cicer arietinum $\mathrm{L}$. & Fabaceae & Shimbra & $\mathrm{H} \mathrm{Cu}$ & Grain & $\begin{array}{l}\text { Diabetes and } \\
\text { general } \\
\text { weakness }\end{array}$ & $\begin{array}{l}\text { Roast the grain of Cicer arietinum as "Kolo" or cook it as "Nifro" or utilize the roasted powder as } \\
\text { "Shiro." }\end{array}$ \\
\hline Carica papaya $\mathrm{L}$ & Caricaceae & Papaya & $\mathrm{T} \mathrm{Hg}$ & $\begin{array}{l}\text { Fruit } \\
\text { and } \\
\text { Grain }\end{array}$ & $\begin{array}{l}\text { Gastritis } \\
\text { Helminthiasis }\end{array}$ & $\begin{array}{l}\text { Without processing or in raw condition, eat the fruit of Carica papaya } \\
\text { Dry and crush the grain of Carica papaya and drink it with tea. }\end{array}$ \\
\hline Cinnamomum verum $\mathrm{L}$. & Lauraceae & Kerefa & $\mathrm{T} \mathrm{Cu}$ & bark & Diabetes & Boil the bark of Cinnamomum verum in water and mix it with tea or honey. \\
\hline $\begin{array}{l}\text { Citrus aurantifolia } \\
\text { Christm. }\end{array}$ & Rutaceae & Lomi & Sh Hg & Fruit & Microbial disease & $\begin{array}{l}\text { Pour the juice of the fruit of Citrus aurantifolia on uncooked vegetables as a salad or mix it with } \\
\text { tea. }\end{array}$ \\
\hline & & & & & Cancer & $\begin{array}{l}\text { Eat the fruit as it is. } \\
\text { The fruit or juice of the plant. }\end{array}$ \\
\hline Citrus sinensis L. & Rutaceae & Birtukan & $\mathrm{Sh} \mathrm{Hg}$ & Fruit & Microbial disease & The fruit or juice of the plant. \\
\hline Cucurbita pepo $\mathrm{L}$. & Cucurbitaceae & Duba & $\mathrm{H} \mathrm{Hg}$ & Fruit & $\begin{array}{l}\text { Gastritis } \\
\text { Helminthiasis }\end{array}$ & $\begin{array}{l}\text { Eat the fruit of Cucurbita pepo after being boiled. } \\
\text { Roast the dried seed of the plant. }\end{array}$ \\
\hline Daucus carota $\mathrm{L}$. & Apiaceae & Carrot & $\mathrm{H} \mathrm{Hg}$ & root & Cancer & Eat the fresh, unprocessed, or roasted and cooked, juice of Daucus carota root. \\
\hline Eragrostis tef $\mathrm{L}$. & Poaceae & Dabbo teff & $\mathrm{H} \mathrm{Cu}$ & Grain & Anemia & Consume the grain powder of Eragrostis tef as "injera" or "atmit" gruel. \\
\hline Guizotia abyssinica L.f. & Asteraceae & Nug & $\mathrm{H} \mathrm{Cu}$ & Grain & Bronchitis & $\begin{array}{l}\text { Eat the grain of Guizotia abyssinica after being roasted, well ground. } \\
\text { Prepare the "Kolo" from Hordeum vulgare and Cicer arietinum by boiling them with water and } \\
\text { drunk after being filtered. }\end{array}$ \\
\hline Hordeum vulgare L. & Poaceae & Gebis & $\mathrm{H} \mathrm{Cu}$ & Grain & Gastritis & $\begin{array}{l}\text { Dehulled, roast, and then ground the grain of Hordeum vulgare and mix the } \\
\text { powder with water and honey or sugar as "beso" or the roasted hulled grain of the plant as" Kolo." }\end{array}$ \\
\hline & & & & & $\begin{array}{l}\text { Osteoporosis or } \\
\text { general weakness }\end{array}$ & Hull the seed of Hordeum vulgare, roast and grind it and cook it like porridge. \\
\hline Linum usitatissimum $\mathrm{L}$. & Linaceae & Telba & $\mathrm{H} \mathrm{Cu}$ & Grain & $\begin{array}{l}\text { Gastritis } \\
\text { constipation, } \\
\text { Breast cancer, } \\
\text { attention deficit }\end{array}$ & $\begin{array}{l}\text { Soak the seed of Linum usitatissimum with water, boil it, cool it, and drink it. } \\
\text { Place the seed of Linum usitatissimum in any form, but usually the roasted and ground one, in the } \\
\text { glass and mix it with warm water. }\end{array}$ \\
\hline
\end{tabular}




\begin{tabular}{|c|c|c|c|c|c|c|}
\hline Lupinus albus L. & Fabaceae & Gibto & $\mathrm{H} \mathrm{Cu}$ & Grain & Hypertension & $\begin{array}{l}\text { Consume the seed of Lupinus albus after being soaked for 2-3 days to remove its bitter taste. } \\
\text { Then, it is roasted, boiled, and spiced with onion and pepper or processed in the local way "areki" } \\
\text { synthesized to prepare "Gibto areki." }\end{array}$ \\
\hline $\begin{array}{l}\text { Lycopersicon } \\
\text { esculentum } \\
\text { Mill. }\end{array}$ & Solanaceae & Timatim & $\mathrm{H} \mathrm{Hg}$ & Fruit & $\begin{array}{l}\text { Anemia, heart } \\
\text { disease and } \\
\text { cancer }\end{array}$ & $\begin{array}{l}\text { Consume the juice, fresh or canned, of Lycopersicon esculentum; whole fresh or } \\
\text { canned or crushed diced fruit or as tomato paste or soup. }\end{array}$ \\
\hline Nigella sativa $\mathrm{L}$. & Ranunculaceae & $\begin{array}{l}\text { Tikur } \\
\text { azmud }\end{array}$ & $\mathrm{Sh} \mathrm{Hg}$ & Grain & $\begin{array}{l}\text { Constipation, liver } \\
\text { disease } \\
\text { and general } \\
\text { weakness }\end{array}$ & Eat the powdered seed of Nigella sativa, mixed with honey or bread, or chew the seed directly. \\
\hline Sesamum orientale $\mathrm{L}$. & Pedaliaceae & Selit & $\mathrm{H} \mathrm{Cu}$ & Grain & Diarrhea & Consume the seed of Sesamum orientale or the roasted seed mixed on a loaf of bread as a spice. \\
\hline Solanum tuberosum $\mathrm{L}$. & Solanaceae & Dinich & $\begin{array}{l}\mathrm{H} \mathrm{Hg} \text {, } \\
\text { and } \\
\mathrm{Cu}\end{array}$ & Tuber & Gastritis & The tuber of Solanum tuberosum in the form of juice. \\
\hline Sorghum bicolor $\mathrm{L}$. & Poaceae & Zengada & $\mathrm{H} \mathrm{Cu}$ & Grain & $\begin{array}{l}\text { Hypertension and } \\
\text { diabetes }\end{array}$ & The grain powder of Sorghum bicolor is a form of "atmit" or "injera." \\
\hline $\begin{array}{l}\text { Triticum dicoccon } \\
\text { Schrank }\end{array}$ & Poaceae & Ajja & $\mathrm{H} \mathrm{Cu}$ & Grain & $\begin{array}{l}\text { Diabetes, blood } \\
\text { pressure, } \\
\text { Rheumatism and } \\
\text { osteoporosis }\end{array}$ & $\begin{array}{l}\text { The flour from the grain of Triticum dicoccon as bread or "atmit" or the } \\
\text { crushed seed as "Kinchie" or soup. }\end{array}$ \\
\hline Triticum aestivum $\mathrm{L}$. & Poaceae & Sendie & $\mathrm{H} \mathrm{Cu}$ & Grain & Constipation & $\begin{array}{l}\text { The whole grain flour of Triticum aestivum is "injera" or bread. Also, the } \\
\text { seed is roasted as "Kolo." }\end{array}$ \\
\hline Thymus schimperi $\mathrm{R}$. & Lamiaceae & Tosign & $\mathrm{H} \mathrm{Wd}$ & leaf & $\begin{array}{l}\text { Hypertension and } \\
\text { microbial } \\
\text { disease }\end{array}$ & The leaf of Thymus schimperi boiled with water. \\
\hline $\begin{array}{l}\text { Trigonella foenum- } \\
\text { graecum } \mathrm{L} \text {. }\end{array}$ & Fabaceae & Abish & $\mathrm{H} \mathrm{Cu}$ & Grain & $\begin{array}{l}\text { Gastritis } \\
\text { hypertension and }\end{array}$ & $\begin{array}{l}\text { Grind the germinated and dried seed of Trigonella foenum-graecum and } \\
\text { Soak it with water for one night, withdraw the filtrate to minimize its bitterness, and mix it with } \\
\text { water and drink it or boil and drink it with honey or sugar. }\end{array}$ \\
\hline Urtica simensis Steudel & Urticaceae & Sama & $\mathrm{H} \mathrm{Wd}$ & leaf & $\begin{array}{l}\text { Poliomyelitis } \\
\text { Gastritis }\end{array}$ & $\begin{array}{l}\text { Grind the grain, mix it with water, put it at the child's back under the sun, and stroke it slowly. } \\
\text { Pick the leaves of Urtica simensis carefully with a protected hand, cut the leaves, spread them out } \\
\text { b/n two hides on the ground, and rub them to avoid the burning sensation of the leaves; after that, } \\
\text { boil and grind, then put salt on and prepare them. }\end{array}$ \\
\hline Vicia faba $\mathrm{L}$. & Fabaceae & Bakela & $\mathrm{H} \mathrm{Cu}$ & Grain & $\begin{array}{l}\text { Bronchitis } \\
\text { Gastritis }\end{array}$ & $\begin{array}{l}\text { Boil the Vicia faba grain and get water to drink. } \\
\text { Drink roasted and powdered Vicia faba grains soaked in water overnight. }\end{array}$ \\
\hline Zingiber officinale Mill & Zingiberaceae & Zingiber & $\mathrm{H} \mathrm{Hg}$ & rhizome & $\begin{array}{l}\text { Microbial disease } \\
\text { Badmouth odor }\end{array}$ & $\begin{array}{l}\text { Place a few pieces of Zingiber officinale in a cup of boiling water, strain, and drink. } \\
\text { Chewing the rhizome as it is and rinsing the mouth with water }\end{array}$ \\
\hline
\end{tabular}

Note: $\mathrm{Hb}$ : habit, H: herb, T: tree, Sh: shrub; H: habitat, Hg: home garden, $\mathrm{Cu}$ : cultivated; Pp: plant parts used 
Table 7. List of human diseases in the study area with several functional food plants (NFFP) used to prevent them.

\begin{tabular}{llcc}
\hline Disease prevented & $\begin{array}{c}\text { Local name of the } \\
\text { disease }\end{array}$ & NFFP & Percentage \\
\hline Gastritis & Yechegoara beshita & 8 & 27.5 \\
Hypertension & Yedem gfit & 7 & 24.1 \\
Cancer & Cancer & 5 & 17.2 \\
Diabetes mellitus & Yeskuar beshita & 5 & 17.2 \\
Microbial disease & Worershign & 5 & 17.2 \\
Constipation & Yehod dirket & 4 & 13.8 \\
General weakness & Yeakim medakem & 4 & 13.8 \\
Osteoporosis & Yeatint melashek/Sibrat & 3 & 10.3 \\
Rheumatism & Kurtimat & 2 & 6.9 \\
Bronchitis & Yesal beshita & 2 & 6.9 \\
Heart disease & yelib himem & 2 & 6.9 \\
Anemia & Deme manes & 2 & 6.9 \\
Helminthiasis & Yehod telatil & 2 & 6.9 \\
Attention deficit & Yeamro zigemet & 1 & 3.4 \\
Badmouth odor & Motifo yeaf teren & 1 & 3.4 \\
Breast cancer & Yetuit cancer & 1 & 3.4 \\
Diarrhea & Tekimat & 1 & 3.4 \\
Liver disease & Yegubet beshita & 1 & 3.4 \\
Poliomyelitis & Yelejinet lemisha & 1 & 3.4 \\
\hline
\end{tabular}

Table 9. Methods of preparation of functional food plants

\begin{tabular}{lcc}
\hline Methods of preparation & $\begin{array}{c}\text { No. of FFP } \\
\text { species }\end{array}$ & Percentage \\
\hline Cooking/boiling & 11 & 37.9 \\
Raw/unprocessed & 6 & 20.7 \\
Powdering and baking & 5 & 17.2 \\
Fluid juice & 5 & 17.2 \\
Powdering and boiling & 4 & 13.8 \\
Crushing & 3 & 10.3 \\
Roasting & 3 & 10.3 \\
Roasting and crushing & 3 & 10.3 \\
Crushing and cooking & 2 & 6.8 \\
Boiling and grinding & 1 & 3.4 \\
Roasting, powdering, & 1 & 3.4 \\
soaking and & 1 & \\
Soaking and roasting & 1 & 3.4 \\
Dehulling and roasting & 1 & 3.4 \\
Powdering soaking & 1 & 3.4 \\
\hline
\end{tabular}

Table 8. List of human diseases that are prevented by more than three functional food plants in the study area

\begin{tabular}{|c|c|c|c|c|c|c|}
\hline Family name & Scientific name of the plant & Vernacular name & $\begin{array}{l}\text { Disease } \\
\text { prevented }\end{array}$ & $\begin{array}{l}\text { Local name of } \\
\text { the disease }\end{array}$ & $\begin{array}{l}\text { No. of } \\
\text { plant }\end{array}$ & Percentage \\
\hline Caricaceae & Carica papaya & Papaya & Gastritis & Yecheguara & 8 & 27.6 \\
\hline Cucurbitaceae & Cucurbita pepo & Duba & & beshita & & \\
\hline Poaceae & Horedeum vulgare & Gebs & & & & \\
\hline Lineaceae & Linum usitatissimum & Telba & & & & \\
\hline Solanaceae & Solanum tuberosum & Dinich & & & & \\
\hline Fabaceae & Trigonella foenum graecum & Abish & & & & \\
\hline Urticaceae & Urtica simensis & Sama & & & & \\
\hline Fabaceae & Vicia faba & Bakela & & & & \\
\hline Alliaceae & Allium sativum & Nech shinkurt & Hypertension & Yedem gfit & 7 & 24.1 \\
\hline Chenopodiaceae & Beta vulgaris & Key sir & & & & \\
\hline Fabaceae & Lupinus albus & Gibto & & & & \\
\hline Poaceae & Sorghum bicolor & Zengada & & & & \\
\hline Poaceae & Triticum dicoccon & Ajja & & & & \\
\hline Lamiaceae & Thymus schimperi & Tosign & & & & \\
\hline Fabaceae & Trigonella foenum graecum & Abish & & & & \\
\hline Alliaceae & Allium sativum & Nech shinkurt & Cancer & Nekersa & 6 & 20.7 \\
\hline Brassicaceae & Brassica carinata & Yabeshagomen & & & & \\
\hline Rutaceae & Citrus aurantifolia & Lomi & & & & \\
\hline Rutaceae & Citrus sinensis & Birtukan & & & & \\
\hline Linaceae & Linum usitatissimum & Telba & & & & \\
\hline Pedaliaceae & Sesamum orientale & Selit & & & & \\
\hline Alliaceae & Allium sativum & Nech shinkurt & Microbial & Worershign & 5 & 17.2 \\
\hline Rutaceae & Citrus aurantifolia & Lomi & disease & Wण & & \\
\hline Rutaceae & Citrus sinensis & Birtukan & & & & \\
\hline Lamiaceae & Thymus schimperi & Tosign & & & & \\
\hline Zingiberaceae & Zingiber officinale & Zinjibil & & & & \\
\hline Poaceae & Avena sativa & Engedo & Diabetes & Yeskuar beshita & 5 & 17.2 \\
\hline Fabaceae & Cicer arietinum & Shimbra & & & & \\
\hline Lauraceae & Cinnamomum verum & Kerefa & & & & \\
\hline Poaceae & Sorghum bicolor & Zengada & & & & \\
\hline Poaceae & Triticum dicoccon & Ajja & & & & \\
\hline Brassicaceae & Brassica carinata & Yabeshagomen & Constipation & Yehod dirket & 4 & 13.8 \\
\hline Ranunculaceae & Nigella sativa & Tikur azmud & & & & \\
\hline Linaceae & Linum usitatissimum & Telba & & & & \\
\hline Poaceae & Triticum aestivum & Sendie & & & & \\
\hline Poaceae & Avena sativa & Engedo & General & Yeakim medakem & 4 & 13,8 \\
\hline Fabaceae & Cicer arietinum & Shimbra & weakness & & & \\
\hline \multirow[t]{2}{*}{ Poaceae } & Hordeum vulgare & Gebs & & & & \\
\hline & Nigella sativa & Tikur azmud & & & & \\
\hline
\end{tabular}




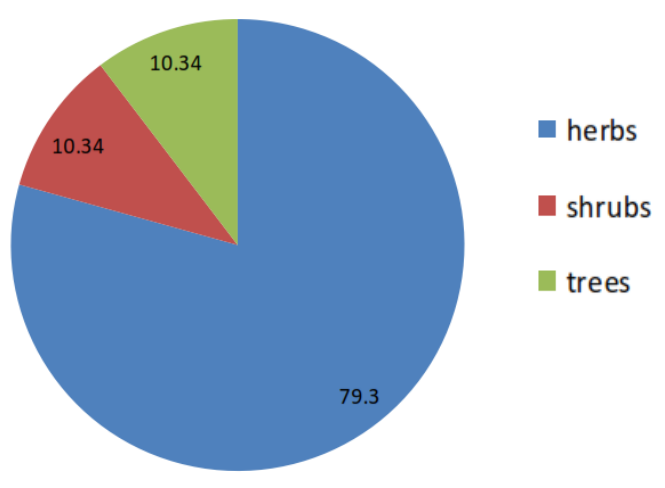

Figure 5. Habits (growth forms) of functional food plants in the study area

\section{Major plant use categories of functional food plants used by the people in the study area}

The research area yielded 29 plants with high Functional Food values. The community uses plants for a variety of purposes in addition to their functionalities. Informants in the study area identified six different types of use (Table 10). As a result, 2,257 use reports (ur) are recorded from 94 frequency of occurrences for the total use category, with each informant reporting on 29 Functional Foods Plants. Plants used in construction have the highest ICF value (0.98), followed by functional food plants and forage use-category, with ICF values of (0.97). This research revealed that ethnobotanical knowledge is homogeneous, and plant use reports from informants on various plant use categories are highly consistent.

\section{Informant consensus (FFP use report) of popular functional food plants}

The use of informant consensus is one method of verifying the efficacy of a given plant species. Common functional food plants cited by most local people in an area were recorded and analyzed in these cases. As a result, 72 (90\%) informants cited Lupinus albus (Gibto), while 63 (79.8\%) informants cited Eragrostis tef (Dabbo teff) for their functionality as health care, and others are shown in

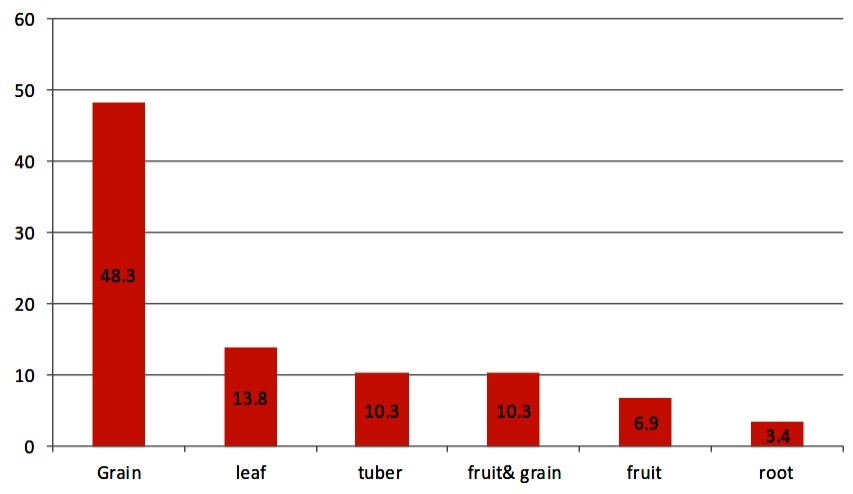

Figure 6. Plant part used as a functional food

Table 11. The popularity of these functional food plants may be due to their effectiveness or the ease with which they can be obtained.

\section{Preference ranking of functional food plants used to prevent gastritis}

Several plant species can protect against a single disease. In such situations, the locals prioritize plant species is based on their ability to avoid a specific disease. Cucurbita pepo (Duba) is the most favored species, followed by Linum usitatissimum (Telba), in this study's preference rating for five plants based on preventing Gastritis (Table 12). The score was determined by seven primary informants and was focused on the ability of each species to avoid Gastritis. The highest value (5) was assigned to species with the highest preventing potential. In contrast, the lowest value (1) was set to species with the lowest preventing potential than the species identified.

On the other hand, specific plant species treat various diseases. Similarly, people prefer plant species that can resist different diseases. Based on disease prevention, a preference ranking conducted by seven primary informants (respondents) for six selected plant species (Table 13) revealed that the most common is Linum usitatissimum $\mathrm{L}$. (Telba), followed by Triticum dicoccon Schrank (Ajja).

Table 10. ICF by use categories of plants for the local people in the study area

\begin{tabular}{lccccc}
\hline \multicolumn{1}{c}{ Use-category } & Species(\#) (nt) & Percentage of species & Use reports (nur) & $\begin{array}{c}\text { Percentage of use } \\
\text { reports }\end{array}$ & ICF (nur-nt/nur-1) \\
\hline Functional food & 29 & 100 & 809 & 35.8 & 0.97 \\
Food/drink & 21 & 72.4 & 557 & 24.7 & 0.96 \\
Spice & 10 & 34.5 & 171 & 7.6 & 0.95 \\
Medicinal plants & 22 & 75.9 & 317 & 14 & 0.93 \\
Forage & 9 & 31.0 & 306 & 4.3 & 0.97 \\
Construction & 3 & 10.3 & & & 0.98 \\
Mean ICF & & & & & 0.96 \\
\hline
\end{tabular}




\section{Direct matrix ranking for multiple uses of functional food plants}

Direct matrix ranking is used to compare multipurpose plants commonly identified by informants. As a result, most people in the study area depend on plants for various reasons, including functionality, food/drink, spice, medicinal, forage, construction, etc. According to the results, Eragrostis tef (Dabbo teff) was ranked first, followed by Hordeum vulgar (Gebis) and Avena sativa (Engedo) (Table 14). According to the informants' reports and the researcher's perspective, local people prefer these plants for different uses and are the most readily available plant species. Thymus schimperi is the lowest in the direct data matrix (Tosign). This is most likely due to its scarcity in the study field. As a result, the utility of resources is determined by their availability.
Table 11. List of functional food plant species reported by thirty and more number of informants

\begin{tabular}{llcc}
\hline Scientific name & $\begin{array}{c}\text { Vernacular } \\
\text { name in } \\
\text { Amharic }\end{array}$ & $\begin{array}{c}\text { Number } \\
\text { of } \\
\text { informants informants }\end{array}$ & $\begin{array}{c}\text { Percentage } \\
\text { of }\end{array}$ \\
\hline Lupinus albus & Gibto & 72 & $90.0 \mathrm{~s}$ \\
Eragrostis tef & Dabbo teff & 63 & 78.8 \\
Avena sativa & Engedo & 54 & 67.5 \\
Cucurbita pepo & Duba & 51 & 63.8 \\
Linum usitatissimums & Telba & 49 & 61.3 \\
Citrus aurantifolia & Lomi & 49 & 61.3 \\
Hordeum vulgare & Gebis & 48 & 60.0 \\
Allium sativum & Nech shinkurt & 43 & 53.8 \\
Triticum dicoccon & Ajja & 39 & 48.8 \\
Lycopersicon esculentum & Timatim & 37 & 46.3 \\
Trigonella foenum graecum & Abish & 36 & 45.0 \\
\hline
\end{tabular}

Table12. Preference ranking of functional food plants used to prevent gastritis by key informants (respondents)

\begin{tabular}{|c|c|c|c|c|c|c|c|c|c|}
\hline Functional food plant & R.4 & $\mathbf{R . 5}$ & R.16 & R.20 & R.39 & R.42 & R.53 & Total & Rank \\
\hline Cucurbita реро & 4 & 5 & 5 & 4 & 4 & 5 & 5 & 31 & 1 \\
\hline Hordeum vulgare & 5 & 3 & 4 & 4 & 5 & 1 & 4 & 26 & 3 \\
\hline Linum usitatissimum & 3 & 5 & 5 & 4 & 4 & 5 & 4 & 30 & 2 \\
\hline Trigonella foenum graecum & 4 & 5 & 1 & 3 & 4 & 3 & 2 & 22 & 5 \\
\hline Urtica simensis & 3 & 4 & 3 & 1 & 5 & 3 & 4 & 23 & 4 \\
\hline
\end{tabular}

Table 13. Preference ranking of six selected functional food plants on the degree of preventing several diseases by key informants (respondent)

\begin{tabular}{lccccccccc}
\hline Functional Food plant & $\mathbf{R . 1 1}$ & $\mathbf{R . 2 8}$ & $\mathbf{R . 4 3}$ & $\mathbf{R . 6 2}$ & $\mathbf{R . 6 7}$ & $\mathbf{R . 7 3}$ & R.80 & Total & Rank \\
\hline Cicer arietinum & 3 & 2 & 3 & 4 & 4 & 3 & 3 & 22 & 3 \\
Linum usitatissimum & 5 & 5 & 4 & 4 & 5 & 5 & 4 & 32 & 1 \\
Lycopersicon esculentum & 1 & 1 & 5 & 2 & 1 & 2 & 1 & 13 & 6 \\
Nigella sativa & 2 & 2 & 1 & 3 & 4 & 2 & 1 & 15 & 5 \\
Trigonella foenum graecum & 2 & 3 & 2 & 2 & 3 & 2 & 5 & 19 & 4 \\
Triticum dicoccon & 4 & 5 & 4 & 5 & 5 & 3 & 4 & 30 & 2 \\
\hline
\end{tabular}

Table14. Direct matrix analyses of selected functional food plants

\begin{tabular}{|c|c|c|c|c|c|c|c|c|}
\hline \multirow[b]{2}{*}{ Species } & \multicolumn{6}{|c|}{ Use category } & \multirow[b]{2}{*}{ Total } & \multirow[b]{2}{*}{ Rank } \\
\hline & 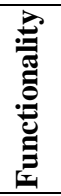 & 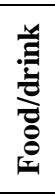 & $\stackrel{\circlearrowright}{\ddot{\mathscr{L}}}$ & 氖窇 & 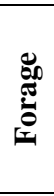 & 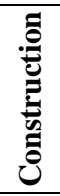 & & \\
\hline Avena sativa & 5 & 4 & 0 & 5 & 5 & 1 & 20 & 3 \\
\hline Cicer arietinum & 3 & 5 & 0 & 2 & 4 & 0 & 14 & 7 \\
\hline Eragrostis tef & 5 & 5 & 0 & 2 & 5 & 5 & 22 & 1 \\
\hline Guizotia abyssinica & 4 & 4 & 2 & 4 & 5 & 0 & 19 & 4 \\
\hline Hordeum vulgare & 4 & 5 & 0 & 4 & 4 & 4 & 21 & 2 \\
\hline Lycopersicon esculentum & 3 & 4 & 4 & 4 & 0 & 0 & 15 & 6 \\
\hline Thymus schimper & 3 & 0 & 5 & 3 & 2 & 0 & 13 & 8 \\
\hline Vicia faba & 3 & 5 & 0 & 4 & 4 & 0 & 16 & 5 \\
\hline
\end{tabular}

Note Use values are given from 0 to 5; 5: Best, 4: very good, 3: good, 2: less, 1: least, and 0: no value. 
Table 15. Fidelity level indexes for plant species used to treat Diabetes mellitus and hypertension in the study area

\begin{tabular}{cclccc}
\hline Disease & $\begin{array}{c}\text { Percentage } \\
\text { of informants }\end{array}$ & Species & NP & N & $\begin{array}{c}\text { Fidelity level } \\
\text { index (NP/N) }\end{array}$ \\
\hline Diabetes mellitus & 67.5 & Avena sativa & 35 & 54 & 0.65 \\
& 21.3 & Cicer arietinum & 10 & 17 & 0.58 \\
& 11.3 & Cinnamomum verum & 7 & 9 & 0.78 \\
& 78.8 & Eragrostis tef & 26 & 63 & 0.41 \\
Hypertension & 10 & Sorghum bicolor & 28 & 39 & 0.75 \\
& 48.8 & Triticum dicoccon & 5 & 11 & 0.72 \\
& 13.8 & Thymus schimperi & 38 & 43 & 0.45 \\
& 53.8 & Allium sativum & 10 & 18 & 0.88 \\
& 22.5 & Beta vulgaris & 6 & 8 & 0.56 \\
& 10 & Sorghum bicolor & 64 & 72 & 0.75 \\
& 90 & Lupinus albus & 26 & 39 & 0.89 \\
\hline
\end{tabular}

\section{Fidelity level index of functional food plants used to prevent diabetes and hypertension}

The percentage of informants who claim to use certain plant species for the same main reason or to confirm the effectiveness of plant species in assessing its value is known as the fidelity level (FL) (Amenu 2007). Fidelity level index was measured for functional food plants used to Prevent Diabetes and Hypertension, and the results showed that Cinnamomum Verum (Kerefa) and Lupinus albus (Gibto) have the highest Functional value to avoid diabetes and hypertension, with $(\mathrm{FL}=0.78)$ and $(\mathrm{FL}=0.89)$, respectively (Table 15).

\section{Description of most cited (ten top) functional food plants in the study area with their functionality}

All functional food plants $(10$ species $)$ cited by informants above $45 \%$ (Table 11) are described below.

\section{Lupinus albus L. (Fabaceae) GIBTO (Amh.)}

Lupinus albus L. is an herbaceous plant with a shortly hairy, bushy steam; lower leaves have obovate leaflets, and upper leaves obovate-cuneate. It has a white to the blue corolla. The pod is villous and glabrescent, and the seeds are smooth. The plant is prevalent to be planted in Gojjam. In the study region, the seed is primarily used to prevent hypertension. According to Nigussie (2012), people in northwestern Ethiopia used "Gibto Areki" as a locallymade antihypertensive medicine. In Ethiopia, the fruit and seed of this plant are both used for the same functional reason, according to Ragunathan and Solomon (2009).

\section{Eragrostis tef L. (Poaceae) TEFF (Amh.)}

Eragrostis tef L. is a cultivated herb that grows in tufts and can reach a height of $120 \mathrm{~cm}$ in cultivated plants. The leaf blades are narrow, and the panicle is folded and depressed at the base; the spikes are grey or golden, with up to ten florets, and the seedlings are tiny and delicate. Ethiopia is home to this species. Two types of teff are grown in Ethiopia: white grain (Nech teff) and brown grain (Dabbo teff). The seeds of this plant, especially Dabbo teff, are used to prevent anemia and diabetes mellitus in some parts of the world (lower blood glucose). Teff contains omega-3 fatty acids, which have been linked to a reduced risk of heart attacks and prostate tumor development, as well as omega- 6 fatty acids, which have been linked to a reduced risk of cardiovascular disease, and docosahexaenoic acids, which have been linked to a reduced risk of breast cancer, according to different authors cited on SUDASR23 (2010).

\section{Avena sativa L. (Poaceae) ENGEDO (Amh.)}

The herb Avena sativa L. is cultivated. It may appear as a wheat contaminant or escape near cultivations on rare occasions. Culms are simple, erect, and $40-180 \mathrm{~cm}$ tall. The uppermost florets are reduced to $1.7-3 \mathrm{~cm}$ long and nonshuttering, and the florets lack a basal bearded callus. The glumes are narrowly elliptic, oblong, and acute. Lemmas are robust and glabrous hairy around the awn insertion, measuring $1.2-2.5 \mathrm{~cm}$ in length. Ethiopia is typically grown at $2,700-3,000 \mathrm{~m}$, particularly in areas where soil fertility is declining, preferred over barley. Forage is made out of crop residue. The plant's seed was traditionally used to lower blood sugar, prevent osteoporosis, and improve overall health. According to Lance and Garren (2002), beta-glucan in the seed can lower blood cholesterol and help prevent heart disease, and the seed of this plant can also control gastrointestinal function.

\section{Cucurbita pepo L. (Cucurbitaceae) DUBA (Amh)}

Cucurbita pepo $L$. is an annual herb with ascending, creeping, or bushy, 5-angled stems up to 15 meters long in some varieties. The branched shallow root stem grows from a well-developed taproot. Scabrous and setose stems branch and sometimes root at the noods. It has unisexual yellow flowers on the same plant as the male. The fruit was cooked simply with water and eaten when cool to prevent Gastritis, and the seeds were roasted and eaten to avoid helminthiasis. In various studies, pumpkin (Duba) and other vegetables are functional plant-based foods. For example, Braun and Cohen (2007) looked at how betacarotene in pumpkin affects the immune and hormonal systems and its ability to protect against lung cancer. 
Linum usitatissimum L. (Linaceae) TELBA (Amh)

Flax is a slender annual herb that grows to a height of 0.3 to 0.9 meters. It has thin, pale green alternating leaves and branches at the end. One or two delicate blue flowers are tipped on each unit. The locals used the seed of this plant to prevent Gastritis, Constipation, and Breast Cancer and boost attention deficiency. Still, some informants advised that a child taking "absho" for this purpose should avoid flaxseed as a side effect. According to the following, the alpha-linolenic acid, lignans, and fiber in flaxseed have possible health benefits such as reducing cancer, diabetes, osteoporosis, atherosclerosis, autoimmune, arthritis, cardiovascular disease, and neurological disorder Martinchik et al. (2012). Aside from that, it helps with menopausal symptoms and attention deficit disorder. Furthermore, according to Roizen and Oz (2005), eating flax seeds regularly will improve real age by 3.4 years due to monounsaturated fats.

\section{Citrus aurantifolia L. (Rutaceae) LOMI (Amh)}

It's an evergreen shrub that grows up to 5 meters tall and has a lot of short sharp spines on the stems and beside the leaves. The leaves are oval and delicate, with a gleaming green color. Flowers are white, and the fruit is round or oval, up to $6 \mathrm{~cm}$ in diameter but typically more petite, with a thin green or yellow peel. The pulp is green, acidic, and juicy. The locals used these plant fruits to protect themselves from microbial diseases and "nekersa". According to Wondimu et al. (2000), the community of "Dheerra city" used the fruit of this plant as a nutraceutical to treat flu, wounds, stomach ache, and skin rash. On the other hand, Hasegawa and Miyake (1996) discovered that the phytochemical limonoids in citrus fruits were responsible for anticancer activity.

\section{Hordeum vulgare L. (Poaceae) GEBIS (Amh)}

Hordeum vulgare $L$. is an upright, stout, and tufted annual grass. The leaf is truncate and 1-2 mm long. The leaf blades measure $10-15 \mathrm{~mm}$ in width. The flower anthers are three, and the ovary is pubescent at the apex. It has a caryopsis fruit with an adherent pericarp. The local community used the plant to prevent Gastritis as a type of "Beso" or underlying "Kolo," and it was also thought to provide extra strength during illness and for mothers during childbirth as a form of "Gonfo." According to RoblesEscajeda et al. (2013), bioactive compounds found in barley (Beta-glucans, tocotrienols, and poly-phendlunasin) have anti-cancer properties.

\section{Allium sativum L (Alliaceae) NECH SHINKURT (Amh)}

It's a cultivated herb found in home gardens and farmland. Bulb ovoid with a white coat that encloses the bulb leaf. The bulbs used to prevent hypertension and microbial and "nekersa" were found in the research field. To name a few, the supposed health benefits include cancer chemoprevention, antibiotic, anti-hypertensive, and cholesterol-lowering properties (Srivastava et al. 1995). The bulb of this plant had a nutraceutical benefit to treat flue and lung abscess in the population of "Dheerra city," according to Wondimu et al. (2000). Ernst (1997), on the other hand, discovered that alliums could protect against cancer of the gastrointestinal tract. Triticum dicoccon Schrank (Poaceae) AJJA (Amh)

It's solid or thick-wailed annual cultivated grass culms. Rhachis is glabrous or shortly ciliated at the nodes, fragile, disarticulating above the spikelet insertion, spikelet falling attached to the internode below; spikelets 3-10 cm long, laterally compressed; rhachis glabrous or shortly ciliated at the nodes, fragile, disarticulating above the spikelet insertion, spikelet falling attached to the internode below. Glumes 7-10 mm long, coriaceous with a single prominent keel; lemma with an awn up to $15 \mathrm{~cm}$ long; spikelet 3(4) flowered. The locals in the study area used this food plant to treat diabetes Miletus, hypertension, and cholesterol in the blood and maintain general health and bone strength, often as a form of "Atmit." Phytochemical saponins and functional component B-glucan in oat help lower LDL cholesterol, reduce blood pressure, and lower heart disease risk.

\section{Lycopersicon esculentum Mill. (Solanaceae) TIMATIM (Amh)}

It's an annual or perennial herb with petiolate leaves that alternate. Flowers have two sexes. Above the base, pedicels articulate. The calyx is strongly 5-lobed, and the yellow corolla is stellate. It has 5 stamens of similar length and a bilocular or plurilocular ovary with false septae. The fruit is a berry that is red or orange and has elliptical seeds. The locals claimed that eating fresh tomatoes or tomato paste could help them avoid anemia and heart disease. On the other hand, Krinsky and Johnson (2005) say that the phytochemical lycopene found in tomatoes helps prevent prostate cancer. This phytochemical in tomatoes has also been shown to inhibit the growth of breast, lung, cervical, ovarian, and pancreatic tumors, according to Rao and Rao (2007).

In conclusion, the study's findings showed that indigenous people in the study region have traditional knowledge and practices on functional food plants that they have learned over centuries. The majority of the area's usable food plants are grown at home and in the field. Only one species, Urtica simensis steudel, is purchased from the market for consumption, and it is a rare wild species in the area. Herbs were the most commonly used functional food plants, followed by shrubs and trees. Seeds have also been the most frequently used plant parts in Functional Food. Although the residents' favorite method of preparing functional food plants is cooking/boiling, most are prepared this way. Almost all functional food plants in the study area were expected because they are everyday demands of their daily life activities. Still, one of the most commonly cultivated functional food plants in Gojjam, Lupinus albus, is under threat due to the loss of agricultural lands in the case of construction as the Woreda is developed into an administrative town, responsible stakeholders should make such strong effects. It was also stated that when suffering from the disease, information transfer among the population about the functionality of foods was presupposed. As a result, it is critical to continue building a safe citizen documentation of functional food plants by 
passing on information to current and future generations to raise our awareness and avoid chronic diseases triggered by a drastic change in our lifestyle and environmental effects.

\section{REFERENCES}

Abbasi AM, Khan MA, Shah MM, Prevez A, Ahmed M. 2013 Ethnobotanical appraisal and cultural values of medicinally important wild edible vegetables of Lesser Himalayas-Pakistan. J Ethnobiol Ethnomed 9: 66. DOI: 10.1186/1746-4269-9-66.

Alexiades M. 1996. Collecting Ethnobotanical Data. In: Alexiades H Sheldon JW (eds). An introduction to basic concepts and techniques selected guidelines for ethnobotanical research: A manual. New York Botanical Garden. Bronk, NY, USA.

Amenu E. 2007. Use and management of medicinal plants by indigenous people of Ejaji area (Chelya woreda) west Showa, Ethiopia: An Ethnobotanical Approach. [Thesis]. Addis Ababa University, Ethiopia.

Asfaw Z. 2001. The role of home gardens in production and sustainable use of Medicinal Plants in Ethiopia. IBCR, Addis Ababa, Ethiopia.

Braun L, Cohn M. 2007. Herbs and Natural Supplements. Elsevier, Australia.

Cotton CM. 1996. Ethnobotany: Principle and application. John Wiley and Sons Ltd., West Sussex, UK.

DMDHHIV/AIDSPCO. 2015. Debre Markos District health and HIV/AIDS prevention and control office annual report (unpublished).

DMDFEDO. 2015. Debre Markos District finance and economic development office annual report (unpublished).

DMDARDO. 2015. Debre Markos District rural and agricultural development office annual report (unpublished).

Ernst E. 1997. Can Allium vegetables prevent cancer? Phytomedicine 4: 79-83. DOI: 10.1016/S0944-7113(97)80032-3

Eskin NAM, Tamir S. 2006. Dictionary of nutraceuticals and functional foods. CRC Press, USA.

FAO. 1995. Non-woody forest product and nutrition. In: Report of the International Experts Conclusion On Non-Woody Forest Product. FAO, Rome, Italy.

Hasegawa S, Miyake M. 1996. Biochemistry and biological functions of citrus limonoids. Food Rev Intellectuals 12: 413-435. DOI: $10.1080 / 87559129609541089$
Kassaye KD, Amberbir A, Getachew B, Mussema Y. 2006. A historical overview of traditional medicine practice and policy in Ethiopia. Ethiopian J Health Dev 20 (2): 128-134. DOI: 10.4314/ejhd.v20i2.10023.

Krinsky NI, Johnson, EJ. (2005). Carotenoid actions and their relation to health and disease. Mol Aspects Med 26 (6): 459-516. DOI: 10.1016/j.mam.2005.10.001

Wang L, Bohn T. 2012. Health Promoting Food Ingredients and Functional Food. In: Bouayed J (ed). Nutrition, Well-Being, and Health. IntecOpen, London, UK.

Martin GJ. 1995. Ethnobotany: A Method Manual. Springer, NY.

Martinchik AN, Baturin AK, Zubtsov VV, Molofeev VIU. 2012. Nutritional value and functional food properties of flaxseed. Voprosy Pitaniia 8 (3): 4-10.

Nigussie Z. 2012. Contribution of white Lupin (Lupinus albus L.) for food security in North-Western Ethiopia: A Review. Asian J Plant Sci 11: 200-205.

Ragunathan M, Solomon M. 2009. The study of spiritual remedies in Orthodox rural churches and traditional medicinal practice in Gondar Zuria District, North-Western Ethiopia. J Pharmacogn 1: 178-183.

Rao AV, Rao LG. 2007. Carotenoids and human health. Pharmacol Res 55 (3): 207-216.

Roberfroid M. 2003. Functional food concept and its application to prebiotics. Dig Liver Dis 2: S105-110. DOI: 10.1016/s15908658(02)80176-1

Robles-Escajeda E, Lerma D, Nyakeriga MA, Ross JA, Kirken RA, Aguilera RJ, Varela-Ramirez A. 2013. Searching in mother nature for anti-cancer activity: anti-proliferative and pro-apoptotic effect elicited by green barley on leukemia/lymphoma cells. PLoS One 8 (9): e73508. DOI: 10.1371/journal.pone.0073508.

Roizen ME. Oz MC. 2005. You, The Owner"es Manual: An Insider"s Guide to the Body That Will make you Healthier and Younger. Harper Collins Publisher, Inc., New York.

Ross S. 2000. Functional Food: The Food and Drug Administration Perspective. Am J Clin Nutr 71 (6): 1735s-1738s.

Srivastava KC, Bordia A, Verma SK. 1995. Garlic Allium sativum for disease prevention. South Afr J Sci 91: 68-77.

SUDASR23. 2010. Nutritional Data on SkipThepie.org. "Teff uncooked" https://skipthepie.org/cereal-grains-and-pasta/millet-flour/comparedto/teff-uncooked. [July 2016]

Wondimu T, Asfaw Z, Kelbesa E. 2000. Ethnobotanical study of food plants around "Dheerra" Town, Arsi, SINET: Ethiopia. J Sci 29 (1): 71-80. 